\title{
ARCHITECTURAL MONUMENTALISM IN TRANSITIONAL ALBANIA
}

ROMEO KODRA

Tirana Art Lab

Albania, 1001 Tirana, Sulë Gjashta 28

romikodra@gmail.com

iD orcid.org/0000-0002-5001-0894
DOI: $10.17234 /$ SEC.29.6

Original scientific paper

Received: 25. 3. 2017.

Accepted: 15. 9. 2017.

This article is an open access article distributed under the terms and conditions of the CC BYNC-ND 4.0 license.

This essay is focused on the artistic concept of monumentalization, in this case in architecture and urban planning, and, through some historical examples, investigates and traces the role of this concept inrelation with the construction of representative political power. The chosen context is that of Albania, and more specifically Tirana, during the last 100 years, where three main political models - fascism, state socialism and contemporary neoliberal practices - with their analogies and developments in terms of relation with arts, have produced subjectivities and generated meanings in public space.

Keywords: monumentalization, arts, politics, significance, subjectification

\section{INTRODUCTION}

This essay is part of a larger research focused on arts' space (architecture, visual arts, performing arts, etc.) and its rationalization or conditioning by political power. The context chosen is that of contemporary Albania, Tirana and its monumental boulevard. Regarding monuments and monumentalization, the basic concept of the essay is that of Jacques Le Goff, who once asserted:

"[A] monument is primarily a disguise, a deceptive appearance, a montage. First of all, it must be dismantled, demolishing the montage, deconstructing the construction and analyzing the conditions in which those documents-monuments were produced" (Le Goff 1978:38-43). 
Accordingly, the research is undertaken because of the need for a deconstruction and a reconstruction of the complex social situations occurring during almost a century of independence (since 1912), that remain operative in contemporary Albania. Such situations are historically created by some (still) obscure relationships between the artists and political power representatives that continuously influence the art space.

Regarding the title, the syntagm "transitional Albania" is used to give an idea to the non-Albanian readers that, despite the perpetual dogma promoted by every political power that led the country from its creation, as an independent state Albania is still seen as being under construction and an ongoing process towards something unattainable. The architectural monumentalization of the main boulevard in Tirana is taken as a paradigm in the essay to represent this stalemate, which is strictly connected with the representational aspects of arts as well as political power.

Trying to win over public opinion and to satisfy the need for reconstruction, after centuries of imperial wars, and modernization without eclipsing the tradition, during the last 90 years, three political models ${ }^{1}$ have availed themselves of monumentalization in architecture and urban planning, which was, layer by layer, applied to Tirana's main boulevard. At first glance, the tendencies towards monumentalization in portraying the characteristic representatives of the political power in Albania seem related to a well-known psychoanalysis observation of an infant-subject when it is separated from the mother. In this case, the infant invests objects with the attributes of the mother to compensate and get consolation for this sense of loss. These objects are called Transitional Objects (Winnicott 1953). Moreover, this sense of loss and architectural monumentalism as transitional objectification of this loss, has always imbued the authoritarian political power themes, from Mussolini who wanted to reconstruct the splendour of

\footnotetext{
${ }^{1}$ At first, during the Ahmet Zogu's period (1924-1939), the transition was from a "traditional", "ottoman" society towards a more "modernized", "occidental" one that never arrived completely; then, during the socialist dictatorship (1944-1991), towards a "new communist world" that never arrived completely; and now, during 25 years of "democracy and pluralism" towards the European Union, as if Albania does not belong to the continent, and that still has to be part of it, just because some countries have deterritorialized the "old" Europe and have self-declared themselves part of this new reterritorialized entity.
} 
Roman Empire; to Enver Hoxha who wanted to promote, by means of the socialist realism art, the struggle of the Albanian people through centuries; or Edi Rama who called his winning coalition in 2013 "renaissance" as a clear reference to the European Renaissance and Albanian Renaissance of XIX century that led to the Independence. Furthermore, these themes of political power depicted in monuments and monumentalization, as transitional objects and objectification, wish to recapture what the people, and they as people's representatives, have lost. In this manner they wish to rewrite the history; and then, through re-composition of history's fragmentation, ${ }^{2}$ inscribe their names in it $^{3}$ (Bertinchamps and Derens 2013).

Therefore, all the representative political models have seen an increase in national approval and international prestige following massive initiatives in monumental architecture and urban planning such as the reorganization of entire urban areas, construction of public buildings, monuments, and even new cities. Conversely, several historical centres disappeared, especially in Tirana, Albania's Capital City. Since 1920 an entire urban pattern or fabric almost disappeared without a trace, depriving the city of its identity, ${ }^{4}$ which was then identified and determined exclusively by the authority of the political powers.

This psychotic link between the modern power representatives and monuments and monumentalization, intended as transitional objects, is closely connected with the production of subjectivity and demonstrates a clear misuse of culture by these political power representatives. Indeed, for Eugenio Barba the "[t]ransition is itself a culture" (Barba 1995:5), thus the geographical and historical traumas and fragmentations alluded to in recomposing the representational aspects of historical and geographical

\footnotetext{
${ }^{2}$ I am referring here to Walter Benjamin's concept of history expressed in the famous Angelus Novus' text.

${ }^{3}$ It is emblematic, in this regard, an interview of Albania's Prime Minister and artist Edi Rama: "[I] didn't become Edi Rama because of the politics. I was Edi Rama before. If I stay [in politics], is for doing something. I have a problem with death. It comes from the fact that I am an artist. I have a problem with death and history. I want to leave a name. I am not interested for anything else. I do politics to fight the idea of death."

${ }^{4}$ Actually it is not easy to understand the consistency of this identity as no traces remain from the old city of Tirana, except the mosque and the clock tower.
} 
memory need to be accepted and integrated within the cultural fabric and not refused or viewed superficially (ibid.:14). ${ }^{5}$

\section{EVERYTHING STARTS WITH THE COMPOSITION OF URBAN SPACE}

The Albanian modern urban planning began with topographic mapping in 1917, when the government started to think about an urban plan of Tirana, which was designed by the Austrian engineer Köhler in 1923 (Tashi et al. 2014:4). Yet, according to the critique, it seems ${ }^{6}$ more an adjustment of the existing system of roads than a real urban plan (Dobjani 2010:134). The real "modern" urban planning, according to the Albanian historiography, began in 1925 with Armando Brasini, an Italian rationalist architect and urban planner. He developed Köhler's plan adding an axis, a boulevard that divided Old Tirana, an ottoman style city that was partially modified by the construction of the boulevard, and New Tirana, with new quarters to be developed. In order to understand the reasons for this project - the relation with the political power and its representational aspects - a historic retrospective is needed.

Mussolini, who took power with "the march on Rome" in 1922, had a particular political interest in the Albanian territory. The country was included in his imperialistic optics, which was ultimately established under the "Friendship Pact", signed between the two countries, in Tirana in 1926. The pact signalled the beginning of the Albanian transformation to an Italian protectorate (Iaselli 2006).

The Albanian Prime Minister Ahmet Zogu, fascinated by Mussolini's impressive authoritarian rise to power, in 1927 adopted a policy favouring

\footnotetext{
5 "This fascination with the surface, which today because of the intensity of contacts risks subjecting the evolution of traditions to rapid accelerations, can lead to homogenizing promiscuity. How does one manage to 'eat' the results obtained by others, while also having the time and chemistry to digest those results? The opposite of a colonized or seduced culture is not a culture which isolates itself but a culture which knows how to cook in its own way and to eat what it takes from or what arrives from the outside."

${ }^{6}$ In my opinion there are some indications in Köhler's plan which can be connected with the ideas of Austrian urban planners, such as Camillo Sitte and Otto Wagner.
} 
Italy, which had, for a long time, aided the country financially in order to showcase its resources. Therefore, in 1928, the National Bank of Albania, a subsidiary of the Bank of Italy, and the Italian SVEA (Company for Economic Development of Albania) were founded, guaranteeing a huge loan for the construction of the roads network and the completion of the new capital of Tirana (following Armando Brasini's urban plan), that were exclusively -judging by who the tenders were awarded to-intended for the companies with Italian capital. However, regarding SVEA and all the Italian help, it is important to know that:

"The operation, personally commissioned by Mussolini, had a purely political character: well aware of the incapacity of Albania to pay, the Italian representatives aimed to claim on the loan guarantees in order to gain control primarily on the trade and then on the entire administration of the country." (Iaselli 2004).

In the meantime, the Prime Minister of the Albanian Republic Ahmet Zogu, on September 1928, was proclaimed King Zog I of the Albanian Monarchy. During this period several public works were realized by SVEA: naval ports of Vlora and Durrës, constructions of new roads along the main cities Tirana-Durrës, Shkodër-Elbasan, Durrës-Vlorë, and dozens of bridges.

But soon the ambitious program of public works for Albania provoked a crisis between the Italian SVEA, the Italian government and the Albanian government, the latter having had a huge debt in 1929. It was caused by the corruption of the Albanian King and his administration. The Italian Treasury delivered large sums as loans for public works, but the credit was used, as programmed by Mussolini, to increasingly attract Albania towards the Italian political orbit. During these years, other public works were realized as well: the Durrës-Tirana railroad, new bridges, six ministerial buildings and the renovation of the Villa Reale (King's Residency) designed by Florestano Di Fausto, as well as the Grand Hotel in Tirana. (Giacomelli and Vokshi 2012).

When Brasini studied the urban plan of Tirana in 1925 - whose main element was a great monumental boulevard, oriented north-south and separating the existing ottoman almost-feudal city from its suburbs 
- monumental architecture entirely autonomous and detached from the context was outlined upon it. Paradoxically, the function of this boulevard was to stand as a hinge between the old centre and the modern city, for which no clear instructions were given. In the second half of 1939 Gherardo Bosio, designing the final plan of the Albanian capital city, kept the monumental axis provided by Brasini and integrated it with other buildings.

In the same year, April 7th 1939, the Italian troupes had occupied Albania. One of the reasons used by Mussolini in Italian Parliament as justification for the invasion were the risks that had encumbered Italian investments, mainly due to the abuses by the Albanian King and his administration (Giacomelli and Vokshi 2012).

In addition it must be added that, after the invasion - presented by the Italian media more as an Anschluss (Mussolini 1939), and with the unification of the Albanian Crown under "Vittorio Emanuele III King of Italy and Albania" - the Albanian oil secured one third of the entire Italian (Iaselli 2004:65-104) demand, the Albanian bitumen and chromites covered the entire Italian demand, the Albanian coal and copper its $90 \%$. So, it is clear that "the Italian help" for Albania and Albanians, was not given entirely free.

As planned, returning once more to the urban space of the Albanian capital, Gherardo Bosio was sent to Tirana in the summer of 1939 with the task of organizing a Central Office for Building and Urban Affairs, bringing his expertise as one of the most important architects and urban planners of the fascist's regime to bear. Of course Albanians did not question this choice, first of all, because of the dictatorship installed with the Italian invasion and, secondly, because of the sense of inferiority inspired by the figure of the famous, Western architect.

Bosio's most urgent problem was presented through the identification and organization of new areas as residential neighbourhoods exclusively for Italian colonels and officers, who lived in the ancient city. In addition to the management of the new office, he began with the revision of the old plan, and in 1940 completed the draft of the new building code. In the project there were appropriate buildings provided, all based on the uniform system of a rational plan. It also included precise indications on height, green areas and distance of the architectural blocks from the street line, the use of porticos, as well as the materials and colours to be used on the facades. 


\section{THEATRICALITY}

The colonial interests of the Italian government were strictly connected with spatial composition and demarcation of the territory through the arts of representation. According to Anthony Vidler the spatial forms are:

[...] produced by the psychological culture of modernism from the late nineteenth century to the present, with its emphasis on the nature of space as a projection of the subject, and thus as a harbinger and repository of all neurosis and the phobias of that subject. Space, in this ascription, is not empty, but full of disturbing objects and forms, among which the forms of architecture and city take their place. The arts of representation, in their turn, are drawn to depict such subject/object disturbances, themselves distorting the conventional ways in which space has been described since Renaissance (Vidler 2001:viii).

However, the arts of representation, such as architecture, have two aspects: the representational aspects (visible objects and their movement) and laboratorial aspect (invisible concepts and means of production).

This division is clearer in the art of theatre where the minimal requirement in its foundation is the relationship between an actor and a spectator, who interact in a common space. In this basic relationship, space is defined through the actor's voice and movements. Signs made by the actor in this composed space/the set, in order to articulate and to become semantically essential for the audience, require repetition. In addition to the repetition, an actor is aware that the gestures acted out on stage, in order to be fully conveyed, must be exaggerated (Toporkov 1979:62) ${ }^{7}$ because the theatrical space is not his quotidian space. Theatrical space includes the crew of actors, who interact with one another, but also the spectators seated at the end of the theatre hall, for which the sign or gesture must be made equally discernible as for the ones seated in the front; thus, if this sign is not magnified and/or exaggerated, the distance may cause it to be indistinguishable. Therefore, these are the representational aspects of acting, the constituent part of theatricality that the spectators can notice.

\footnotetext{
7 "Well then, do you see that now you are standing in a completely different rhythm than before? Do you feel the difference? To stand and watch for a mouse - that is one rhythm; to watch a tiger that is creeping up on you is quite another one."
} 
However, there is another part of theatricality which is based on measuring the exaggeration, as taught by Stanislavski, which makes an actor credible while playing a role. Therefore, beyond the representational aspects, there is a whole life, experienced by the performer, that the passive spectator cannot see, which I call laboratorial aspects.

Now, let's turn back and see how "this role is played" by the political power representatives in composing the urban space and how the laboratorial aspects are hidden. If we only look at the main boulevard of Tirana, it is fairly clear that its design is based on Fascist imperial rationalism. The axis (the shape of the boulevard, the Roman "cardo") which marked the territory of the capital was conceived for King Zog I by Italian architects, whose objective was to influence by exaggeration (Butka 1938:174) ${ }^{8}$ the comparative evaluation of the old Ottoman Empire and the new Italian one, ${ }^{9}$ both initially merged in the Albanian King's personality. The citizen of Tirana in the 1930s (a passive spectator) should have been able to understand, through the evidence of theatrical demarcation of his daily space, the mark of the King, behind which the (allied) Mussolinian superiority was hidden.

But, owing to Albanians' neighbours beyond the Adriatic, any mark of the Royal authority on the Albanian urban-architectural space was erased, in a swift and authoritarian manner, on April 1939. If the authoritarian mark of the King was erased, the demarcated ${ }^{10}$ space remained. The Fascist powers, displaying their true Mussolinian imperialistic objectives, found themselves - after the invasion of Albania - playing on a stage which for years had been set up and planned by Italian urban planners and architects (figure 1).

\footnotetext{
8 "There are some long and wide boulevards constructed on fields of grass were sheep and cows are still grazing and, from the other side, main communications roads for the citizens are left as bottlenecks". Qemal Butka, former Tirana's Mayor and one of the most active architect of ' 30 , through this statement can be considered as one of the first professionals of architecture and urban planning to understand the abusive constructions during these years.

9 "Tirana e re / New Tirana", which starts from the boulevard and extended towards the South-West, is the name used to this day to describe an urban zone (a quarter) which corresponds exactly to the part of the city designed by the Italian urban planners.

${ }^{10}$ The demarcation is more evident, above all, in the extraordinary contrast between the architecture and "urban planning" of an ottoman city-village (Tirana was a town of 28.000 peoples) and the urban planning of the modern Fascist rationalism which, to this day, characterizes the Albanian capital, especially its center.
} 


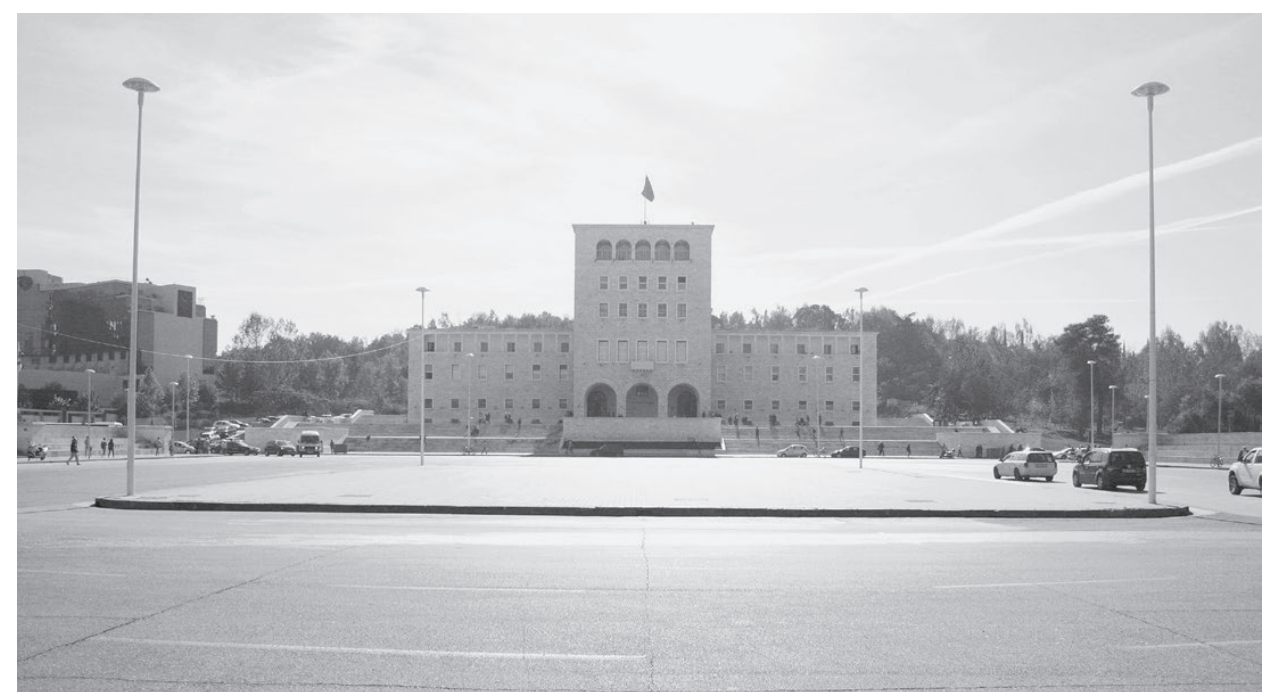

Figure 1: University of Engeneering, ex Casa del Fascio, Mother Theresa Square, Arch. Gherardo Bosio, 1941. Photo: R. Kodra

The day before the invasion King Zog abandoned Albania, thus surrendering the country to Fascism. The occupation, with the exception of a handful of isolated residents near the coasts of Durrës, Shëngjin and Vlora, encountered no resistance from the rest of the population. On the contrary, footage from the era clearly shows the fanfare and parades of citizens welcoming Mussolini's troops. ${ }^{11}$ In other word, despite the heroism of Mujo Ulqinaku (the first martyr of the Albanian Resistance) and the emphasized propaganda of Enver Hoxha's (Hoxha. 1977b:46-47)45-yearlong regime, even in Albanian case no one could shut out the "scream" of Wilhelm Reich in The Mass Psychology of Fascism; in other words, at that particular time the masses wanted (Deleuze and Guattari 1975:32) a fascist regime!

This fact, this quite natural unconditional surrender, is closely connected to the demarcation of space - represented by the theatrical monumentalization of architecture as a sort of new, unknown language

${ }^{11}$ See the extract of "Pushtimi italian i Shqipërisë", a documentary produced by Vizion Plus TV, in https://www.youtube.com/watch?v=_mO5Xgby5_I 
(Lacan 1993:38) $)^{12}$ - to the "producer and planner of reality" (Deleuze and Guattari 2007:29), to a new authoritarian political power that controls the people (Harvey 2003:207) ${ }^{13}$ and objects within a territory, which has undoubtedly influenced the relationship of the Albanian people with the urban space at its very root.

If we focus on the urban-architectural space demarcation through the monumentalism of the rationalist style, it becomes quite evident that it was standardized by Mussolini, in order to disseminate and materialize the idea of the Fascist Empire, ${ }^{14}$ in itself inspired by the ancient Roman Empire. For instance, the axis of Tirana's main boulevard can be found, to this day, reproduced in an almost identical manner, in several other cities (especially in Africa) colonized by the former Fascist Empire, and it functioned not only as a division between the old and new, but also as a chain which joined them, the Mussolinian synthesis which the "indigenous populations" had to understand and perceive as an unique vision of a bright future.

In Mussolinian urban-architectural lingo, the boulevard axis was dubbed "asse cerniera", or the "zipper axis" (Migliaccio 2012),${ }^{15}$ meaning an axis wherein the elements of Albanian and Italian identities are synthesized. Yet, if we take a closer look at the monumental axis of the boulevard and its buildings, despite the effigies of Albanian symbols on the facades, we realize that it resembles a rupture much more than a synthesis (figure 2).

\footnotetext{
12 "It's essential this unknown in the otherness of the Other which characterizes the speech relation at the level at which speech is spoken to the other. [...] Is this all that distinguishes speech? Perhaps, but surely it has other characteristics - it doesn't speak only to the other, it speaks of the other as an object. And this is what is involved when a subject speaks to you of himself."

13 "The sociality of the masses of people drawn to the boulevards was now as much controlled by the imperatives of commerce as by police power." In my research the genealogy of the boulevard as a dispositive of power, thanks to the intuition and following the work of David Harvey on Paris, is the key point to decipher the relation between art and political power in space, which, in this essay, for obvious reasons of length, cannot be further developed.

${ }^{14}$ See in this regard Emilio Gentile Il culto del littorio, 2009.

${ }^{15}$ In her study, Maria Concetta Migliaccio offers, among others, the explicit semantic reasoning behind the placement of the buildings in the urban-architectural zone of the main boulevard, buildings meant specifically for the main institutions of the Albanian state.
} 


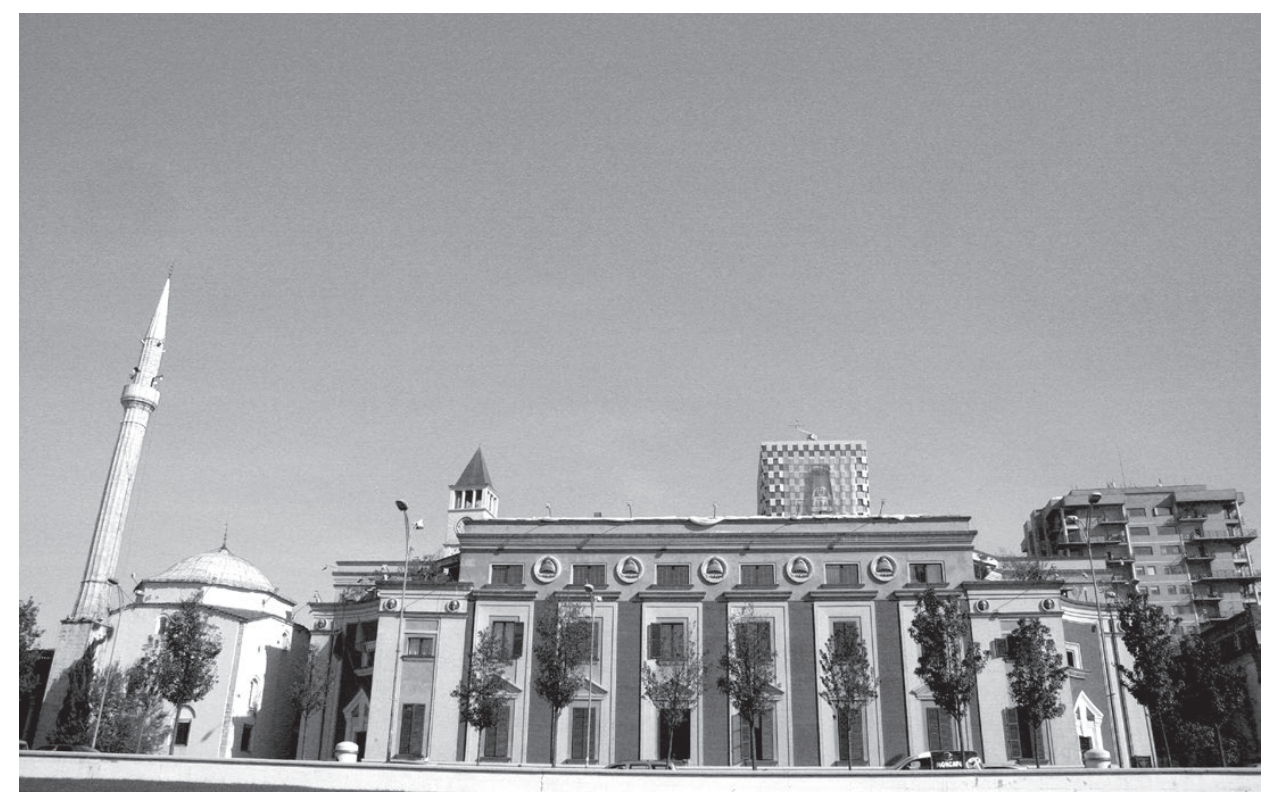

Figure 2: Mosque (1791) and Municipality, Arch. Florestano Di Fausto, 1928. Photo: R. Kodra

Florestano Di Fausto's eclectic ministerial buildings, excluding the above-mentioned symbolic effigies (they too in the pseudo-Roman imperial style) on the facades, have nothing to do with the Albanian context and identity. More than a new synthesized common identity, these buildings transmit identification: the identification of people with their different identities, having their urban space exclusively decided and planned by the incumbent political power.

Relevant to this, it is important to note the disposition of ministerial buildings organized by Di Fausto, where the sequence of the Presidency, the Foreign Affairs Ministry, the Post and Telegraph came to an end on the Mussolini Boulevard and Durrësi Street, ${ }^{16}$ symbolizing a clear semiotic intent reinforcing the idea that the only way for Albania towards modernization and Western Europe passed through this new (hereto unknown) power subject, Mussolini and Italian Fascism.

${ }^{16}$ Durrësi is the city of the main Albanian naval port in Adriatic sea, in front of Italian coast. 
The tendency toward the architectural synthesis is found even after the eclectic style of Florestano Di Fausto, in the later rationalist style of Brasini, Morpurgo, etc. However, Di Fausto's work contains (precisely on the façade of the ministerial buildings) superficial elements of Albanian identity, while the work of Bosio erases and purifies everything for a clear and rational fascist style, as can be seen in the Mother Theresa Square (figure 1), the Prime Ministry Building (figure 3), and Hotel Dajti (figure 4).

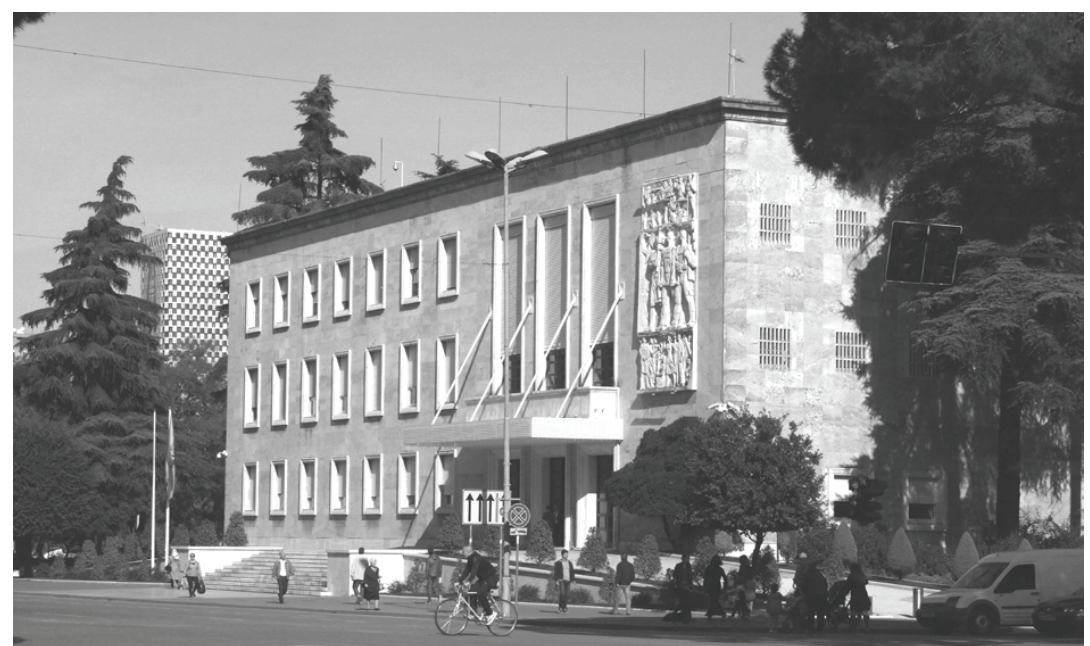

Figure 3: Prime Minister Building, Arch. Gherardio Bosio, 1942. Photo: R. Kodra

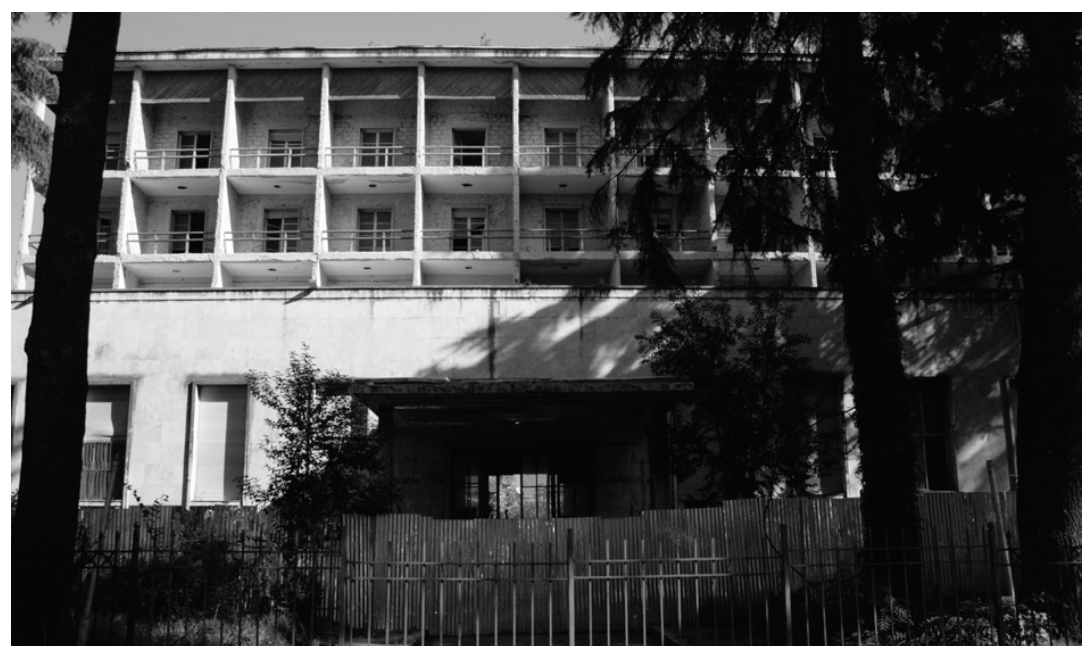

Figure 4: Hotel Dajti, Arch. Gherardo Bosio, 1941. Photo: R. Kodra 
So, despite the synthesis, in this case there is a clear and significant change: it is not a synthesis between the indigenous Albanian/Illyrian and Roman/Italian traditions anymore; it's the architectural synthesis that inscribes Mussolini as an Emperor, through the monumentalism of the rationalist style chosen as the regime's representative, in the glorious history of the reborn Roman Empire.

Lastly, it must be said that the Mussolinian interference, forcing the tendency toward the synthesis to inscribe the new political power in history through a particular architectural style, characterizes the entire rationalist style itself, as stated by one of the most important Italian historians and critics of architecture of the last century, Bruno Zevi:

"[T] he desire to mediate immediately modern postulate without clear references with tradition; ambiguity of meaning not to irritate anyone and indeed to build confidence in the 'classic'stamp, 'ordered', 'logical', 'shiny'; in short, harmless to the desired architectural revolution." (Zevi 1975:183). ${ }^{17}$

And it is through this misunderstanding, misuse and abuse that the Albanian political power representatives promoted the modernity of architecture, urban planning and public space organization in general.

\section{THE LEGACY OF POWER}

According to Thomas A. Markus:

"The essence of teaching the space is that the audience catches a small fragment of a corpus of knowledge at a time, a corpus to which the performer has access. And the fragment is presented as a dramatic spectacle" (Markus 1993:229).

In this regard, considering the buildings and the organization of space on Tirana's main boulevard, what was the lesson taught by the fascist regime, in terms of governance and the representational aspects of power?

\footnotetext{
${ }^{17}$ These are some considerations of Bruno Zevi about architects of Italian rationalism, chosen by Mussolini as the representative style of the Italian Empire.
} 
Enver Hoxha's socialist regime, based on the dictatorship of the proletariat, despite the ideological antagonism with the fascist regime, not only used the same architectural objects of fascism, as in case of "Blloku", ${ }^{18}$ but was influenced and inspired by their model constructing other monumental architectural objects for the demarcation of public space. This influence can be seen in the interventions on the monumental boulevard, especially in the "Presidential Palace" (figure 5) and the "Palace of Culture" (figure 6).

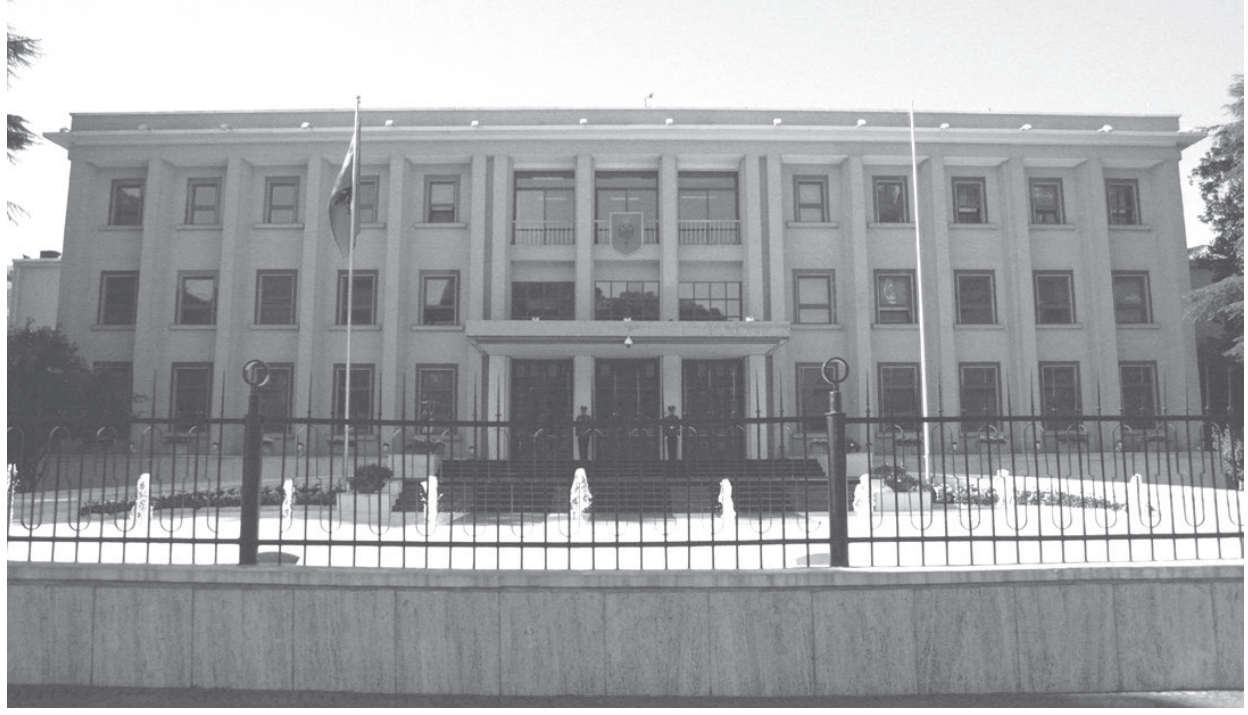

Figure 5: Presidential Palace, unknown Russian architect, finished in 1961.

Photo: R. Kodra

18 "Blloku"/“The Quarter", the former "Leadership's Bllok" that defined the metonymic expression, was based precisely on the semiotic and demarcating Brasini's interpretation of the urban space. King Zog had intended this demarcated and demarcating space, adjacent to the chain-axis-boulevard, on the south-western side of it (New Tirana), as a territory to be used by the privileged and elitist members of his government, having it built at the beginning of the ' 30 s according to the ideas and suggestions of the Fascist Italian experts. However, after 1939, the Fascist invaders used this exclusive space for their officers and ranked officials. During this time, the so-called "aviation buildings" were added, residential 


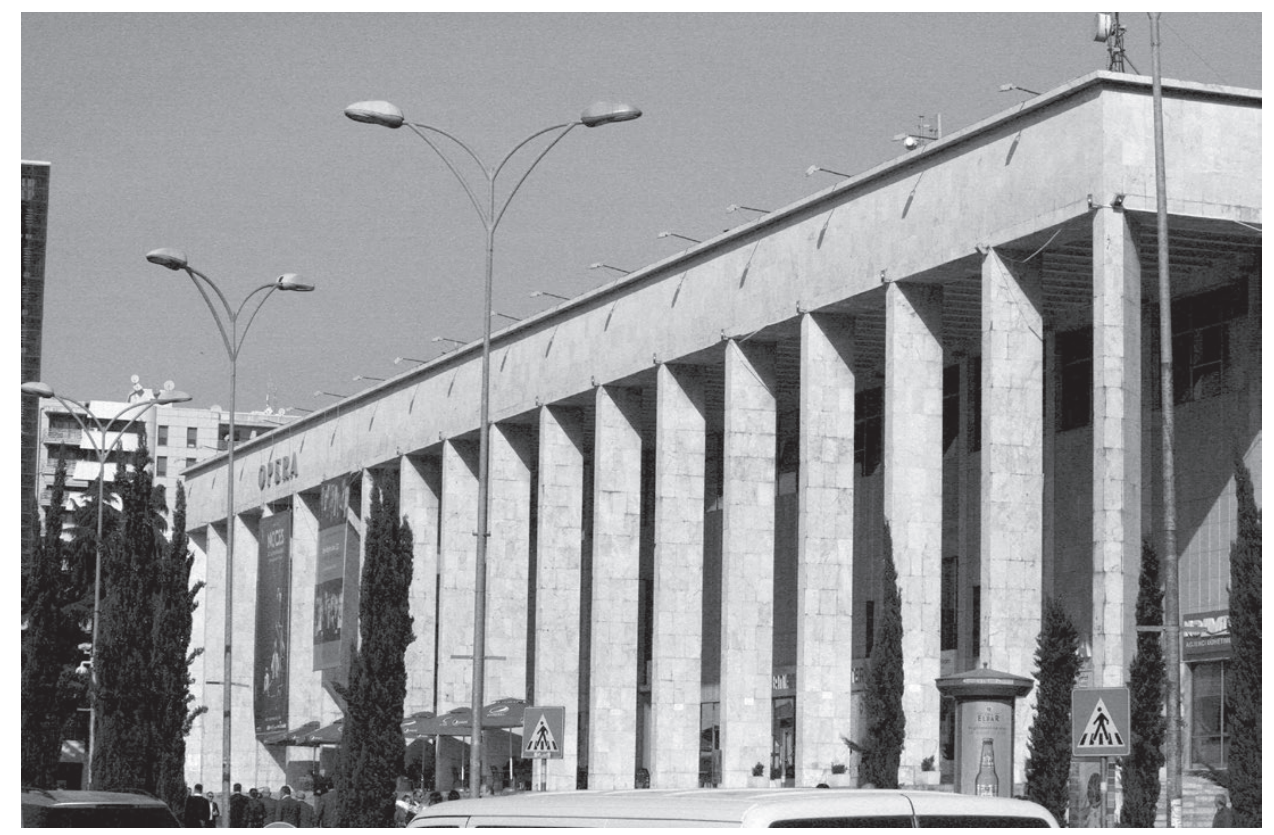

Figure 6: Palace of Culture, unknown Russian architect, finished in 1961. Photo: R. Kodra

It is not paradoxical that it was the most "modern", quasi metaphysical, Italian architectural rationalism that inspired the new regime. Bosio's laconic control of space and the rigid geometric volumes, attractive due to their expressive theatricality, maintaina sort of aristocratic sobriety which also characterized the authoritarian figure of the Albanian dictator Enver Hoxha.

buildings for the pilots of the Italian air force. As stated above Bosio's most urgent problem was presented by the identification and organization of new areas for new residential neighborhoods for Italian colons and officers, who lived in the old part of the city mixed with the Albanian population. Enver Hoxha, the Albanian dictator of the socialist era, following the end of World War II (exactly in 1951) used this exclusive territory as a residential zone of the "Political Bureau". Today, after the fall of regime and the demilitarization of the area (turned in Capital's movida's zone), every owner of a café, pub or disco club (adapted Italian villas) in the "Bllok" area, considers and advertises his proprietary estate as an exclusive and original location, regardless of the monozygotic resemblance which consists specifically of the imaginary contrived exclusiveness that characterizes this space. 
Preserving the same modalities of the demarcation of the space through exaggeration and repetition, focusing on the priority of the semiotic order (Deleuze 2001:53), ${ }^{19}$ on demarcation of the space rather than on the real functionality or rationality, the socialist regime (as the fascists did with the monumental axis) intervened in the north-eastern side of the boulevard, a step beyond fascism, where there used to be an old city with its bazaar. In the name of modernization in the 1970s the old bazaar was destroyed and the old ottoman city was reduced by more than a half (Delisula 2002:8-9).

Yet, on the other hand, in the name of nationalism and the conservation of the Albanian identity (Hoxha 1977a:300) ${ }^{20}$ almost concentrated in the heart of rural areas, the socialist regime contained the further "modern" urbanization. The urban population that was around $20 \%$ before WWII, was not more than 35\% (Aliaj et al. 2009:13) in the '90, after the fall of socialist regime. The containment of the urbanization was possible thanks to the dictatorship of proletariat introduced into the country, its strict control over mobility of the population, its propaganda in favour of the modernization and urbanization of the rural areas. ${ }^{21}$

The totalitarian control of the country by the socialist regime in terms of the administrative apparatus (maintaining the focus of this essay, on architecture), had some similarities with the fascist period. First of all, the control of the urban and architectural constructions was delegated to the aesthetic and ethic expertise of the Institute of Construction. Architecture, when conceived as an art, had to, like any other artistic expression in the socialist regime installed in Albania after WWII, follow the delineation of socialist realism - as in the Soviet Union (Groys 2008:141) - chosen as the unique form of artistic expression permitted at that period in Albania.

19 "[T] conserve or prolong an established historical order, or to establish a historical order which already calls forth in the world the forms of its representation."

20 "Within the inexhaustible and vital sources of [our] people's creativity, we'll find that great inspiration necessary to realize the wonderful and magnificent works for our people." This quote is extracted from a letter of the Albanian dictator Enver Hoxha to Kristaq Rama, Muntaz Dhrami and Shaban Hadëri - sculptors of the Independence Monument in Vlora.

21 "Let us make the village as city" (Ta bëjmë fshatin si qytetin!) was one of the most famous slogans of the period. 
However, architecture, as can be noticed by the lack of a specific Faculty of Architecture till 1969, was not perceived as pure art and was often conceived more as construction engineering. The first architects in Albania graduated in $1974 .{ }^{22}$ For this reason a real debate on the similarities, concepts and semiotic impact of fascist rationalist style and the mixed style of the socialist dictatorship period was never carried out among theorists, historians, and architects. So, even the demarcation of the public space through monumental architecture passed unconsciously and, although declared, it was never theoretically investigated.

This is the first explanation of the reasons for the "pacific" coexistence in Tirana's main boulevard of different architectural styles like the Italian Eclectic Rationalist style, Italian Neo-classic Rationalist style, Soviet Neo-classicist style, mixed and improvised styles inspired by the Italians and Soviet influences, or even Yugoslavian modernism (figure 7), that ideologically - as in other arts where there existed a total censorship of any other artistic method - could not be found in the Albanian context. The second explanation is that, in the case of architecture the demarcation of the space by a superior subject of power still existed. In other words, the induced sense of inferiority of the Albanian subjects (politicians in primis) as simple spectators of foreign subjects' superiority or modernized countries,such as Italy and Soviet Union was still at play.

However, the rigid totalitarian control over the architectural and urban space also meant, according to the statistics based on housing indicators from 1990s, that Albania with its $17 \mathrm{~m}^{2} /$ inhabitant was experiencing a housing space crisis. Albania ranked lowest in Europe, after Romania, the second lowest, that had quasi twice higher space/inhabitant, $35 \mathrm{~m}^{2}$. Compared with the spacious villas in "Blloku", which the Albanian socialist Political Bureau "inherited" after the Nazi-Fascist capitulation, the Albanian housing space was too miserable.

${ }^{22}$ See in Tirana University's webpage http://fau.edu.al/fakulteti/historiku/tradita-qe-prejvitit-1969/ 


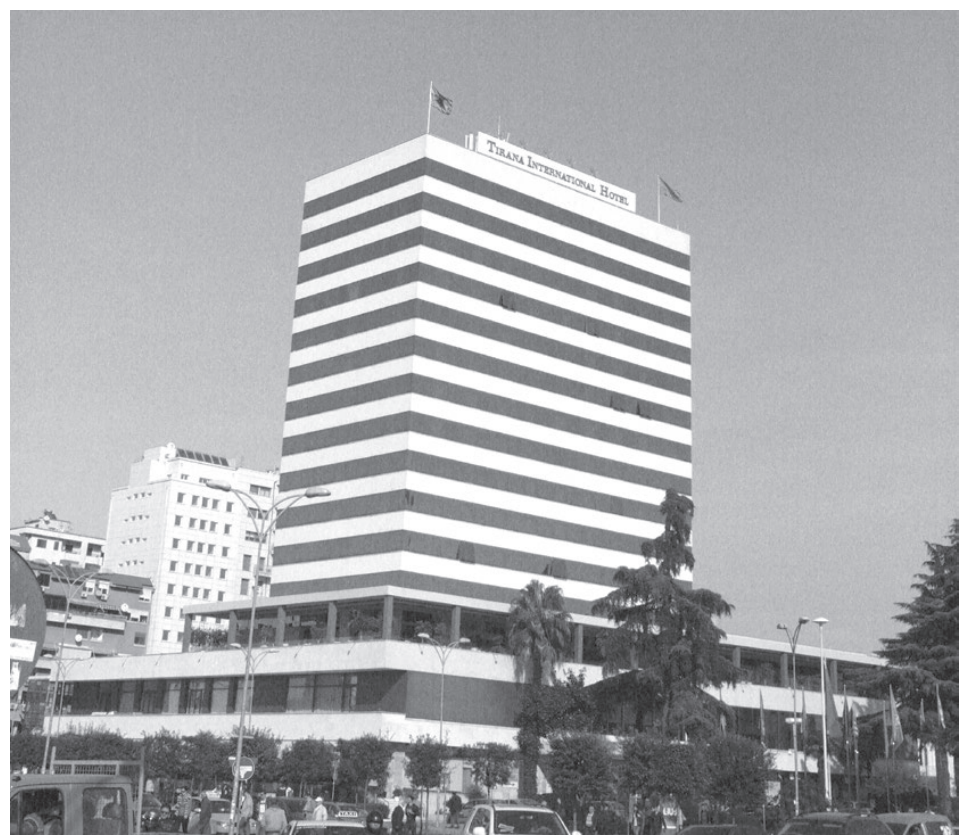

Figure 7: Hotel Tirana, group of architects from National Urban and Architectural Designing Office, 1979. Photo: R. Kodra

\section{THE LEGACY OF THE LEGACY}

In 1991, symbolically marked by the popular destruction of the monument of Enver Hoxha (1908-1985) in Tirana's main square, in that centre stage of Tirana's theatrical boulevard, the expected happened, i.e. the "natural fall" of the socialist regime, because of the total isolation from the rest of the world.

Consequently, the economic collapse of the early 1990s produced a real demographic tsunami followed by an informal architectural boom in the cities, especially in Tirana. With the defragmentation of the monument of the dictator, which was "dismembered" by ferocious workers and students that had blocked the country for months with their strikes, it seemed that that prevalent and authoritarian subject (metaphorically materialized in the monument), which had been occupying the territory for decades, was simply fragmented, in order to be better absorbed in Albania.

It was precisely in 1991, that Edi Rama, a 27-year-old intellectual, visual arts lecturer at the National Academy of Arts, wrote "The tale of the 
goldfishes" (in the Albanian language the goldfish is literally referred to as "redfish", used by the author as a clear reference to the former regime). There he satirizes the transformation of the men of power, servants of the former regime, to whom the "kitchen's ideology master chef" suggested, for survival, not to eat the flesh of the dead red shark (the dictator of the Red Water Republic), but "The model, eat the model" (Klosi and Rama 1991:189). In other words, Rama understood that prevalent authoritarian subject and how easily it survives in Albanian context.

His clear grasp of the very rationale behind thesubject of the political power is demonstrated by his rise to power, which encompassed the revival of the previously prevalent "model" of power in the Albanian context. Being the son of Kristaq Rama, one of the most important Albanian sculptors and deputy of the Popular Socialist Republic of Albania under Enver Hoxha's regime, he began his political carrier as a "Minister of Culture, Youth and Sports", in 1998. In 2000, as the Socialist Party candidate, he won the elections and became Tirana Mayor. His first priority for the city, according to his declarations, was the "urban planning", which would "support all the demographic changes and create the future vision". ${ }^{23}$ However, in the three consecutive mandates as the Mayor of Tirana, the plan was never executed.

What was done is a large scale urban make up ${ }^{24}$ operation demolishing all the illegal buildings on the Lana River (which runs through the centre) and painting the facades of Tirana's main streets buildings. ${ }^{25}$ Despite their feeble transparency, these operations cast many shadows on the illicit infiltrations in Edi Rama's City Council, the change was quite impressive, especially the vivid colours of the facades, which was possible thanks to the collaboration and help of the most important Albanian contemporary artist, Anri Sala, Rama's close friend.

\footnotetext{
${ }^{23}$ Vizion Plus “Zonë e lirë”, July 1st 2013. https://www.youtube.com/watch?v= vFKikDLRzg (min. 24:05).

${ }^{24}$ See the video documentation of the process in the work of Anri Sala, "Dammi i colori". http://www.tate.org.uk/art/artworks/sala-dammi-i-colori-t11813

${ }^{25}$ Actually the re-painting of the facades of the Ministries, Italian eclectic style buildings, on Tirana's main boulevard, previously left in disrepair for more than 15 years, could be considered Rama's first step under the project.
} 
In 2003 the curator Hans Ulrich Obrist and artist Anri Sala, who were invitedtoparticipate in Tirana's Biennale supported by the Mayor Edi Rama, implemented Rama's initial project involving other internationallyrenowned artists such as Olafur Eliasson, Dominique Gonzalez-Foerster, Liam Gillick, Rirkrit Tiravanija, etc.

Nevertheless, let us consider what is behind the vivid colours of the facades. According to Open Data Albania during Rama's years as Mayor of Tirana's Municipality the demographic parameters continued to increase with extraordinary pace. ${ }^{26}$ Consequently, during those years Tirana was affected by architectural bulimia that drowned the city in cement and asphalt; other constructions were built, regardless of the fact that Tirana still does not have a definite master plan in 2015. This also means that the buildings were built illegally, thanks to the inaccuracy of the Municipality, and mostly occupying the public spaces.

\section{BEFORE COMING TO A CONCLUSION}

In June 2013, as the Socialist Party candidate for Prime Minister, Edi Rama won the general parliamentary elections. In August 2013, in a meeting of Next Generation Albania promoted by Edi Rama, George Brugmans, the President of the International Architecture Biennale of Rotterdam, as confirmed by an e mail exchange with the author of this essay, presented the concept of Atelier Albania to the Albanian Prime Minister.

Atelier Albania is a "laboratory" 27 within the National Agency for Territorial Planning chosen after discussions "with Edi Rama, and with the Deputy Prime Minister, Niko Peleshi, and the Minister of Urban Development, Eglantina Gjermeni", as Brugmans explains in the abovementioned e mail. This laboratoryoversees all the urban and architectural competitions organized by the Albanian government on the national scale. None of the other Ateliers created by IABR in countries such

\footnotetext{
${ }^{26}$ See in this link which presents and analyses data released by the Municipality of Tirana http://open.data.al/sq/lajme/lajm/lang/sq/id/262/Popullsia-ne-Tirane-ne-vitet-2001-2009

${ }^{27}$ See the link of the Albanian Agency for Territorial Planning, which is a part of the Albanian Council of Ministers of http://www.planifikimi.gov.al/?q=sq/content/atelieralbania
} 
as Netherlands, Turkey, Brazil, etc., has the privilege of making decisions on all the architectural and urban projects' implemented in the whole country.

In addition, before presenting the concept of the atelier to Edi Rama, Brugmans strategically brought the $51 \mathrm{~N}_{4} \mathrm{E}^{28}$ in. Despitebeing closely linked to the political power and its short life Atelier Albania has already attracted suspicions because of the lack of transparency and a conflict of interests (Hope 2015) ${ }^{29}$ and because of the direct involvement of Rama's friends in public tenders awarded.

Apart fromAtelier Albania, which, being a Western European agency, "guarantees" the aesthetic and ethic quality of the projects chosen for implementation in the territory of Albania, the incumbent government has control over the Albanian Development Fund, the economic and financial tool for its projects.

At this point, some similar traits can be noticed between the different political powers which left their mark onTirana's main monumental boulevard. Although the different political powers that ruled the country share numerous traits in architecture and urban planning, the most visible ones, that at the same time reveal monumentalism as the referential concept for their inscription in history, are: the consequent transitions from simple plaster (or colour of the façades) to marble and glass; the increasing proportions; the clarity or the uniformity of the bright, pure colours; and the theatrical, regular, proportioned composition. The last two traits are also connected with two other processesthat are common to all political power representatives that have governed the Albanian territory. The last two traits have been used as justification for erasing indigenous urban and architectural cultures perceived as retrograde ${ }^{30}$ despite the "modern"ratio of the subject

\footnotetext{
${ }^{28}$ 51N4E is an architectural studio from Brussels known in Albania for the construction of one of ten skyscrapers - which according the plan of Edi Rama Municipal Council should have circumscribed with even more monumental heights the "Italian Ministries" in the center city - and the plan of the central Scanderbeg square in collaboration with the Prime Minister's friend and artist Anri Sala.

${ }^{29}$ See the article of Alan Hope in http://www.flanderstoday.eu/current-affairs/officialarchitect-peter-swinnen-dismissed-immediate-effect

${ }^{30}$ During 1920s, as per Italians urban planners' will, the government of Ahmet Zogu erased only a part of the old city in order to maintain the change towards the modernization of New Tirana visible. During the socialist dictatorship the regime erased the old bazaar
} 
of political power (Pettigrew and Raffoul 1996:39). ${ }^{31}$ In addition, it must be observed that, all these transformations are sort of redundant in light of the progressive abandonment of the first social revolutionary character of the abovementioned political models and their subsequent consolidation of power.

Furthermore, preserving the representational aspects of the monumental architectures, these different political models in the main boulevard express their power maintaining at least one of these aspects: the linearity on the boulevard axis where, as shown in this essay, historically the political power expressed itself as a difference; the verticality of the facades through which the political power highlighted its hierarchic grandeur; and the hermetic closure which was the trait of the exclusiveness and control of the political power.

In addition, the direction of the influence that characterizes architectural expressions of the different political powers must be made evident. First of all, the architectural objects of Tirana's main boulevard were constructed following a top-down decision, which coincided with the will of the incumbent political power (whether Ahmet Zogu's government, fascism, state socialism, or the presenttime, whenthe concept of listening to the public still does not exist).Then, all the monumental buildings on the boulevard reveal openly the "aesthetic"influence from outside-inside with a foreign, modernized and more advanced architectural and urban tradition. Together, these directions top-down and outside-inside form a sort of motion that consists of an infinite spiral that hides behind large financial profits. These profits are firstly supported and assured by expert tools for the aestheticization of the political powers such as the Central Office for Building and Urban Affairs

(the former city center) in the name of "modernization" with consequent gentrification (the intellectual elite representatives such as Ismail Kadare and Dritëro Agolli were the new inhabitants of the new born quarter). In our time the government continues with erasure, e.g. some old houses at the former Train Station in order to expand the main monumental boulevard (gentrification included) or e.g. National Stadium "Qemal Stafa" (with "Cultural Monument" status) built in the Italian Rationalist style, with the same authoritarian modalities in the name of the usual "modernization" or "artistic and cultural" value.

31 "In fact, three points need to be distinguished: the trace, the erasure of the trace and the marking of the erasure. It is at this level that the signifier arises and the subject emerges." 
of GherardoBosio in the fascist period, Institute of Construction during the socialist dictatorship, and Atelier Albania in our days. Secondly, they were supported by the expert financial tools for the implementation of the aestheticization projects such as SVEA in the fascist period, the State Budget in the socialist period, and, in our time, the Albanian Development Fond.

Lastly, although this short description of the architectural monumentalism or monumentalization of political power in Albania seems completely linear, there is something continuously evolving in this territory. It is the instrumentalization of art by political powers. For example, the first step in this evolution could beobserved in the politics of Mussolini during the government of AhmetZogu, which used the art of architecture indirectly, as exemplified by Tirana's main boulevard, in order to influence and exploit the Albanians' sense of inferiority, lack of information, and backwardness. The second step could be observed in the following period of the Italian influence, after the invasion of Albania, where the influence was more direct and decisive, as seen in the pure rationalist style of some boulevard buildings with a superficial tendency towards erasing the synthesis of a common identity Albanian/Illyrian and Italian/Roman both from the facades and the political agenda in order to promote only the representative political power's superior vision. Following the second step ordirect influence, there is the socialist dictatorship method relying on the socialist realism as a sort of disciplinary influence, which exemplifies the evolution of instrumentalization of architecture for themonumentalization of political power. The fourth step, almost original in the modern and contemporary historic panorama, could be the immediate influence of the political power on the arts such as that of Edi Rama, an artist that makes doodles on his daily work papers as the Albanian Prime Minister and an Artist:

"It is a series of pen drawings made in mixed media on old office papers including extracts of his daily agenda, discarded fax pages or other official correspondence of his political office; it is not clear if they are the result of careful concentration or distracted fantasy". 32

\footnotetext{
${ }^{32}$ See in the personal webpage of Lorenza Baroncelli in http://www.lorenzabaroncelli. com/edi-ramas-first-show-in-italy/. Lorenza Baroncelli is an Italian architect, researcher and curator who, despite being Rama's close friend and advisor, was a member of several juries for the competitions regarding urban, architectural and artistic tenders in Albania during Rama's government.
} 
Of course his originality in the modern and contemporary history could not be compared with the political figures that have instrumentalized and influenced the arts for political interests such as Hitler (Welch 1993), ${ }^{33}$ Mussolini (Cannistraro 1975) ) $^{34}$ or Georges Pompidou (DeRoo 2006). ${ }^{35}$ In this case we are looking at a new turn of the screw towards a new era of political exploitation ofthe arts that goes beyond the influence or despotic discipline of the entire society. In Rama's case the representational aspects of art are the political agenda itself. Here the art is not an alternative difference of the political power ratio any more.

The synthesis of the limit-figures ${ }^{36}$ of a politician and an artist in Edi Rama brings to mind the concept of faciality in Deleuze and Guattari where this abstract machine of faciality operates as a codification or semiotic system of two different regimes and apparatus of power: significance and subjectification. Its face or facade is composed of all the other possible faces and facades, all the signifiers (producers of social meanings) and subjectivities (producers of differences). The control of this abstract machine of faciality is absolute:

"Whatever the differences between significance and subjectification, whichever prevails over the other in this case or that, whatever the varying figures assumed by their de facto mixtures - they have it in common to crush all polyvocality, set up language as a form of exclusive expression, and operate by signifying biunivocalization and subjective binarization" (Deleuze and Guattari 1987:180).

\footnotetext{
${ }^{33}$ See David Welch, The Third Reich: Politics and Propaganda, 1993.

${ }^{34}$ See Philip V. Cannistraro,La fabbrica del consenso. Fascismo e mass media, 1975.

${ }^{35}$ See especially chapter 5 Institutionalizing '68. The Pompidou Center The Museum Establishment and Contemporary Art inRebecca J. DeRoo, The Politics of Artistic Display in France after 1968, 2006.

${ }^{36}$ The political power representatives, such as Mussolini, who influenced directly and indirectly the art/ists for political intersts; Enver Hoxha, who disciplined the art/ists: and Edi Rama, who represents a further step, imanent controle of art/ists for political interests. I want to maintain and underline the word limit, because it is connected with a territorial conqest of political power in the field of representation (limit-figures are Mussolini in 1939, Enver Hoxha after 1945 and Edi Rama in our days).
} 
The face or facade of Edi Rama is apolitics (ibid.:181). He is - as his friend and artist Anri Sala likes to define him - the "reality planner" whose bird's eye vision of a landscape demarcates neighbourhoods as zone of thoughts through the cartography of colour. ${ }^{37}$

\section{INSTEAD OF A CONCLUSION}

All the monumental architectural buildings on Tirana's main boulevard were constructed under the control of the incumbent political powers over time. However, there is anarchitectural monument that paradoxically contrasts the others, namely the "Pyramid" (figure 8).

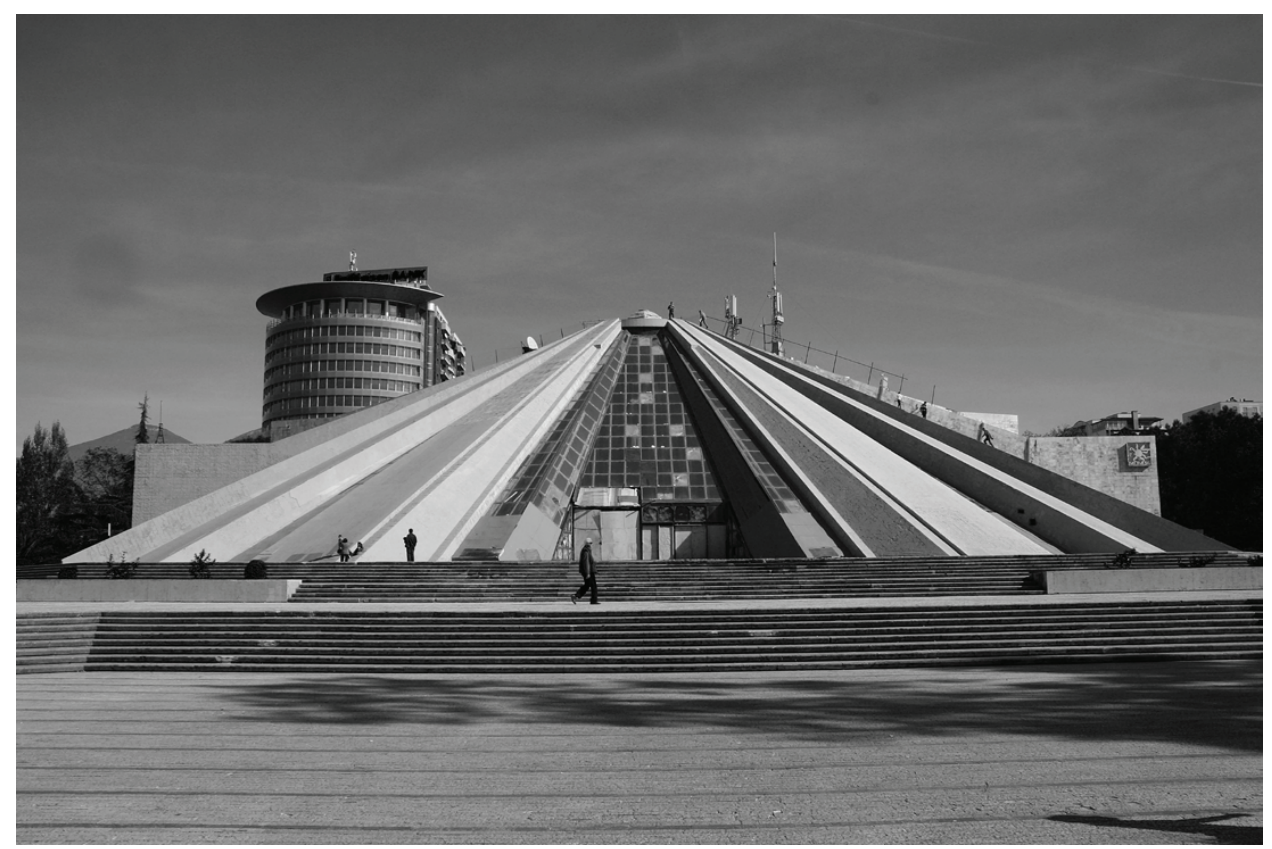

Figure 8: Former »Enver Hoxha Museum « (Pyramid), group of architects: Vladimir Bregu, Pranvera Hoxha, Klement Kolaneci, Pirro Vaso, 1988. Photo: R. Kodra

${ }^{37}$ This quote was extracted from Edi Rama's personal webpage which was available at http://www.edirama.al/files/books/Creating_Space_Where_There_Appears_To_Be None.pdf, but which is no longer accessible since November 2016, the visitors are being redirected to Edi Rama's Official Facebook page. 
The "Pyramid" is the informal name, that reflects the frontal facade's form as seen from the boulevard of the "Enver Hoxha Museum". This building was commissioned by the socialist government immediately after the death of the Albanian dictator, who passed away in April 1986, with the clear intent of glorifying the socialist dictatorship achievements in modernizing the country and bringing progress to the Albanian society.

A group of architects was chosen for the monumental project. They were arch. Vladimir Bregu, arch. Pranvera Hoxha (the dictator's daughter), arch. Klement Kolaneci (Head of the Group as well as Pranvera Hoxha's husband), and arch. PirroVaso.

The familial connections of the two group members with the dictator are mentioned to highlight the extraordinary opportunity created for this group of architects to experiment with modern architecture, in a totally isolated country, with relative freedom, without being suspected of imperialistic and revisionist influences or, worse, accused as enemies of the Party and the Albanian people. The sense of relative freedom is confirmed even by the arch. PirroVaso, in an interview ${ }^{38}$ with the author of the essay. Together with arch. Klement Kolaneci, he presented the final design of the building before the Political Bureau of the Labour Party, the highest level of regime's hierarchy.

And here comes the paradox of the "Pyramid": on the one hand, thanks to artistic experimentation, the most modern architectural monument of Tirana was built on the boulevard; and on the other, it is the clearest example ofa political power representative's monumentalization (Enver Hoxha). Due to the particular conditions created fora group of architects to work freely an extraordinary apologetic monument to dictatorship was erected.

The paradox continues when we consider the integration of the "Pyramid" in the context, intended as a social and urban context, and compared with the other monumental architectural buildings on the Boulevard. Limiting the discourse only to the traits listed in this essay it could be noted that: the "Pyramid", opening a proper space, is not linear to the Boulevard's axis, where the power expresses itself historically; it interrupts the verticality transgressing somehow the hierarchy; using a combination of marble and glass, the classic and modern are unified in

${ }^{38}$ The first of five interviews with Pirro Vaso was conducted on April 2015, in Tirana. 
rendering the monumental building more open, evoking the transparency. Of course there are other monumental architectural buildings along the Boulevard that are not linear to the axis, like the National Gallery (figure 9), or that use the combination of marble and glass, like the Palace of Congresses (figure 10), but none of the monumental buildings contains all three transgressions, in verticality, alignment, and transparency.

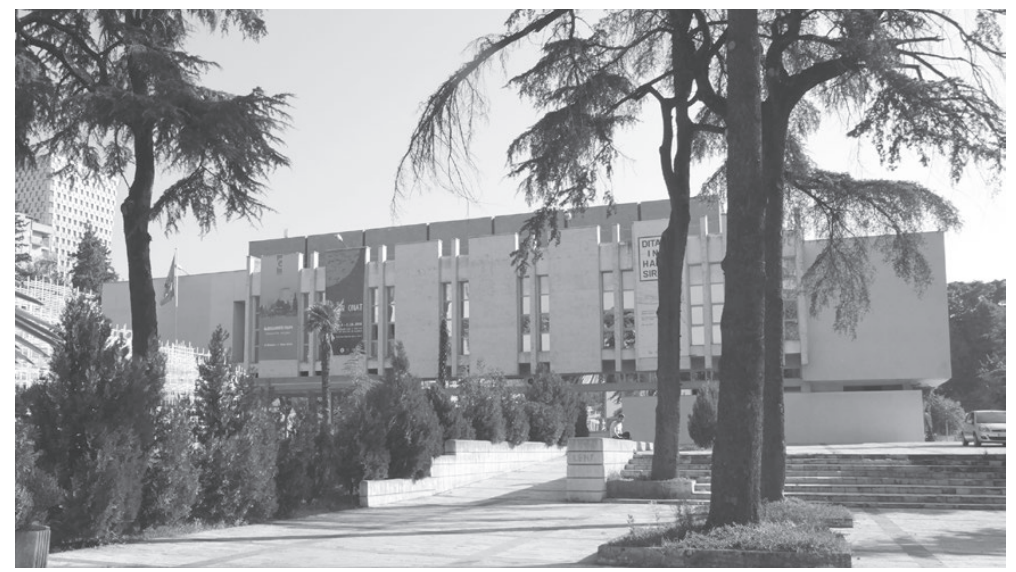

Figure 9: National Gallery of Arts, group of architects from National Urban and Architectural Designing Office, 1974. Photo: R. Kodra

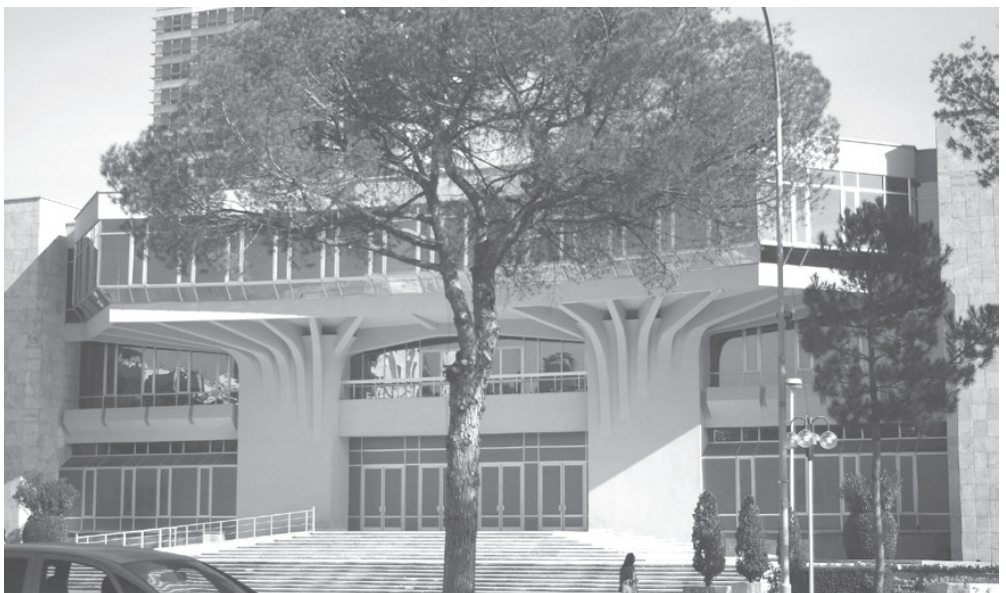

Figure 10: Palace of Congresses, group of architects from National Urban and Architectural Designing Office headed by Klement Kolaneci, 1986. Photo: R. Kodra

Nevertheless, it must be added that "there were no intention to revolutionize anything" in political terms, as confirmed by arch. Pirro Vaso. 
So, all the innovation brought by this group of architects must be seen through the lens of pure artistic, architectural experiments. Furthermore, all the innovative transgressions of the common traits of Boulevard's monumental buildings coincide "unexpectedly" - as admitted by arch. Vaso - with a precise inspiration from direct experience and from the context in which the group of architects was working.

Firstly, the transgression of the verticality is a fruit of a three dimensional star -"made by children during the commemorative Day of the Antifascist Youth" as arch. Vaso remembers - made on the ground by crashing red bricks, till making a sort of red powder used to form the communist star. The architects took that star as the basis for their design, changing its form and creating different shapes.

Then another detail comes to the architect's mind: the lecture of the Italian theoretician and architect Pasquale Carbonara, given in the early 1970s at the Faculty of Architecture, in Tirana. As arch. Vaso still remembers, Carbonara underlined the importance of "the landscape in the rationalist urban planners of the fascist period", the attention "to maintain a relationship", as in Tirana's central square, "with the mountain Dajti" in the Eastern part of the city, the attention to "the height of the buildings" that was almost uniform before the architectural bulimia of the new century. This latter fact influenced even the decision to transgress the alignment of the Boulevard's axis and to give more breath to the monumentality of the building. Lastly, the use of glass was seen more as a modern element of construction and a sort of reduction or containment of the final costs of the building, which amounted to around 5 million USD, the highest cost for a building in the socialist period.

In conclusion, it must be said that the "Pyramid" is the only monumental building in Tirana that, due to its shape, allows for a real performative exchange with the public, a real physical interaction and communication, as exemplified by people climbing daily to the top of the building or graffiti made by street artist, which the political powers try to erase time after time so that they are covered in greyness. ${ }^{39}$ It is perhaps for

\footnotetext{
${ }^{39}$ In Anri Sala's film Dammi i colori, Edi Rama affirms that he painted the multicolored facades of the city because he wanted to change "the socialist period gray facades", "because gray is the color of compromise".
} 
this reason that the "Pyramid" is the only monumental building that - due to the massive protest of intellectuals, former "enemies of the Party and the Albanian people" and ordinary citizens - resisted the neo-liberal pressure (2011-2012), which wanted a new "modern", "democratic" building to erase and replace its collective memory (see in Klosi and Lame 2011).

\section{REFERENCES}

ALIAJ, Besnik, Sotir DHAMO and Dritan SHUTINA. 2009. Midis vakumit dhe energjisë. Tirana: Botimet Afrojdit.

“Atelier Albania”. [s. a.]. Agjencia Kombëtare e Planifikimit të Territorit. http://www. planifikimi.gov.al/?q=sq/content/atelier-albania (accessed June 1, 2017).

BARBA, Eugenio. 1995.The Paper Canoe. London: Routledge.

BERTINCHAMPS, Philippe and Jean-Arnault DÉRENS.2013. "Albanie: Edi Rama, le Premier Ministre et la mort".Le Courrier des Balkans, June 24.https://www. courrierdesbalkans.fr/articles/albanie-edi-rama-le-premier-ministre-et-la-mort. html(accessed June 1, 2017).

BUTKA, Qemal.1938. “Fshati, Qyteti, Kryeqyteti”.Përpjekja Shqiptare. Revistë Kulturale e Përmuajshme, vol. II/16:171-176.

CANNISTRARO, Philip V. 1975.La fabbrica del consenso. Fascismo e mass media. Bari: Laterza.

DELEUZE, Gilles.2001. Difference and Repetition.Trowbridge: The Cromwell Press.

DELEUZE, Gilles and Félix GUATTARI.1975. L'anti-Edipo: Capitalismo e Schizofrenia. Torino: Einaudi.

DELEUZE, Gilles and Félix GUATTARI. 1987. A Thousand Plateaus. Capitalism and Schizophrenia. Minneapolis, Minn.: University of Minnesota Press.

DELEUZE, Gilles and Félix GUATTARI. 2007. L'anti-Edipo: Capitalismo e Schizofrenia. Milano: RCS Libri.

DELISULA, Rezarta. 2002. "Zemra e Tiranës, historia e një shuarje”.Gazeta Shqiptare, December 10, no. 86, f. 8-9.

DEROO, Rebecca J.2006. The Museum Establishment and Contemporary Art. The Politics of Artistic Display in France after 1968. New York: Cambridge University Press.

DOBJANI, Etleva. 2010. "Città e abitazione: Tirana 1920-2006”.Forum $A+P$, vol. 5:134-147.

"Edi Rama's first show in Italy". [s. a.]. lorenzabaroncelli.com. http://www. lorenzabaroncelli.com/edi-ramas-first-show-in-italy/ (accessed June 1, 2017). 
GENTILE, Emilio. 2009. Il culto del littorio. La sacralizzazione della politica nell'Italia fascista. Bari: Laterza.

GIACOMELLI, Milva and Armand VOKSHI.2012.Architetti e ingegnieri italiani in Albania. Firenze:Edifir.

GROYS, Boris. 2008.Art Power. Cambridge, Mass.: MIT Press.

HARVEY, David. 2003.Paris, Capital of Modernity. London: Routledge.

HOPE, Alan.2015. "Official architect Peter Swinnen dismissed with immediate effect". Flanders Toady, February 4.http://www.flanderstoday.eu/current-affairs/officialarchitect-peter-swinnen-dismissed-immediate-effect (accessed June 1, 2017).

HOXHA, Enver. 1977a. On Literature and Art. Tirana: Naim Frashëri.

HOXHA, Enver. 1977b. Resistenza e Rivoluzione - Scritti scelti 1941-1944. Milano: Mazzotta.

IASELLI, Lorenzo. 2004. “L'espansione finanziaria dell'Italia in Albania (1925-1943). La Banca Nazionale d'Albania e la SVEA".Rivista di Storia Finanziaria, vol. 12:65-104.http://www.delpt.unina.it/stof/12_pdf/1.2.pdf (accessed June 1, 2017).

IASELLI, Lorenzo.2006. L'espansione economico-finanziaria italiananei Balcani durante il fascismo. $\mathrm{PhD}$ thesis. Napoli: Università degli Studi di Napoli Federico II. http://www.fedoa.unina.it/651/1/Iaselli.pdf(accessed June 1, 2017).

KLOSI, Ardian and Artan LAME. 2011. Piramida e Tiranës: e hijshme, e braktisur, e rrezikuar. Tirana: Botimet Dudaj.

KLOSI, Ardian and Edi RAMA. 1991. Refleksione. Corfu: Botimet Albania.

LACAN, Jacques.1993. Psychoses. London: Routledge.

LE GOFF, Jacques.1978. “Documento/Monumento".In Enciclopedia Einaudi, vol. V: Divino-fame. Torino: Einaudi, 38-48.

MARKUS, Thomas A. 1993.Building and Power: freedom and control in the origin of modern building types. London - New York: Routledge.

MIGLIACCIO, Maria Concetta. 2012. “Identità e architettura nell'esperienza albanese di Florestano Di Fausto".In Architetti e ingegnieri italiani in Albania, eds.Ezio Godoliand Ulisse Tramonti. Firenze: Edifir, 33-53.https://iris.unipa.it/retrieve/ handle/10447/94999/225041/Albania\%201B.pdf (accessed June 1, 2017).

MUSSOLINI, Benito. 1939.Speech, April 14, Rome. https://www.youtube.com/ watch?v=aO_YVRn1kNs(accessed November, 2016).

PETTIGREW, David and François RAFFOUL. 1996.Disseminating Lacan. Albany, NY.: State University of New York Press.

“Popullsia në Tiranë në vitet 2001-2009”. [s. a.]. open.data.al. http://open.data.al/sq/ lajme/lajm/lang/sq/id/262/Popullsia-ne-Tirane-ne-vitet-2001-2009 (accessed June 1, 2017). 
Pushtimi italian i Shqipërisë. 2009. A documentary produced by Vizion Plus TV, June 17. https://www.youtube.com/watch?v=_mO5Xgby5_I(accessed June 1, 2017).

RAMA, Edi. [s. a.]. Creating Space where there appears to be None. http://www. edirama.al/files/books/Creating_Space_Where_There_Appears_To_Be_None. pdf(accessed November, 2016).

SALA, Anri. 2003.Dammi i colori, video. http://www.tate.org.uk/art/artworks/saladammi-i-colori-t11813(accessed June 1, 2017).

TASHI, Parashqevi, Ani TOLA, Armand VOKSHI and Adriana MIRI. 2014. "Transformation of space between dwellings in the city of Tirana from 1920 to early 1960s. Case study: The existing situation and regulatory plans of Tirana from its establishment until 1960”. In ICRAE2014 Conference- Paper Proceedings. The $2^{\text {nd }}$ International Conference on Research and Educatıon - "Challenges Toward the Future" (ICRAE2014), 30-31 May 2014, University of Shkodra "Luigj Gurakuqi", Shkodra, Albania.http://konferenca.unishk.edu.al/icrae2014/cd/pdfdoc/345. pdf(accessed June 1, 2017).

TOPORKOV, Vasily Osipovich.1979. Stanislavski in rehearsal: the final years. New York: Theatre Arts Books.

“Tradita prej vitit 1969”. [s. a.]. Fakulteti i Arkitekturës dhe Urbanistikës, Universiteti Politeknik $i$ Tiranës. http://fau.edu.al/fakulteti/historiku/tradita-qe-prej-vitit-1969/ (accessed June 1, 2017).

VIDLER, Anthony. 2001. Warped Space: art architecture, and anxiety in modern culture. Cambridge, Mass.: MIT Press.

WELCH, David. 1993. The Third Reich: Politics and Propaganda. London: Routledge.

WINNICOTT, Donald Woods. 1953. "Transitional Objects and Transitional Phenomena”. International Journal of Psycho-Analysis, vol. 34:89-97.

ZEVI, Bruno.1975. Storia dell'architettura moderna. Torino: Einaudi.

Zonë e lire. 2013.A program of Vizion Plus TV, July 2nd. https://www.youtube.com/ watch? $\mathrm{v}=$ _vFKikDLRzg(min. 24:05)(accessed June 1, 2017). 
Romeo Kodra

\section{MONUMENTALIZAM U ARHITEKTURI TRANZICIJSKE ALBANIJE}

Ovaj se rad bavi umjetničkim konceptom monumentalizacije, u ovom slučaju one u arhitekturi i urbanističkom planiranju te istražuje i prati ulogu ovog koncepta u odnosu na izgradnju reprezentativne političke moći. Odabrani kontekst je Albanija, točnije Tirana, tijekom posljednjih 100 godina, u kojoj tri glavna politička modela - fašizam, državni socijalizam i suvremene neoliberalne prakse - svaki sa svojim analogijama i razvojem u pogledu odnosa prema umjetnosti, proizvode subjektivnosti i generiraju značenja u javnom prostoru.

Ključne riječi: monumentalizacija, umjetnost, politika, značenje, subjektifikacija

\section{MONUMENTALIZMI ARKITEKTUROR NË SHQIPËRINËE TRANZICIONIT}

Kjo ese ka në fokus konceptin artistik të monumentalizimit, në këtë rast në arkitekturë dhe planifikim urban dhe nëpërmjet disa shembujve historik, hulumton dhe ravijëzon rolin e këtij koncepti në lidhje me konstruktimin e pushtetit politik përfaqësues. Konteksti në fjalë është ai shqiptar, më konkretisht ai i Tiranës përgjatë 100 viteve të fundit, ku tre modele politike kryesore - fashizmi, socializmi shtetëror dhe praktikat neoliberale bashkëkohore, me analogjitë dhe zhvillimet e tyre në lidhje me marrëdhënien me artin, kanë prodhuar subjektivitete dhe gjeneruar kuptime në hapësirën publike.

Fjalë kyç: monumentalizim, artet, politikat, shenjeshmëria, subjektifikimi

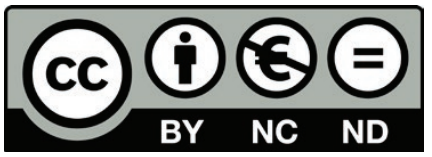

Articles published in this journal are Open Access and can be distributed under the terms and conditions of the Creative Commons license Attribution-NonCommercial-NoDerivatives 4.0 (http://creativecommons.org/licenses/by-nc-nd/4.0/) 